\title{
OCA2 Gene
}

National Cancer Institute

\section{Source}

National Cancer Institute. OCA2 Gene. NCI Thesaurus. Code C131349.

This gene plays a role in transport and melanin synthesis. 